\title{
Kerentanan Ekosistem Mangrove terhadap Ancaman Gelombang Ektrim/Abrasi Di Kawasan Konservasi Pulau Dua Banten
}

\author{
MUDMAINAH VITASARI \\ Pendidikan IPA Universitas Sultan Ageng Tirtayasa \\ *email: md3vitasari@gmail.com \\ Manuscript received: 19 Mei 2015 Revision accepted: 29 Juli 2015
}

\begin{abstract}
Ekosistem Mangrove merupakan ekosistem unik di pesisir sebagai pelindung daratan baik pelindung dari abrasi, intrusi dan sebagai habitat berbagai macam spesies. Besarnya fungsi mangrove ini akan sangat disayangkan ketika terjadi kerusakan karena akan berdampak ke berbagai aspek seperti matinya spesies, berubahnya garis pantai karena abrasi, masuknya air asin ke air tanah dan lain sebagainya sehingga perlunya pemeliharaan ekosistem ini. Pemeliharaan ini perlu dilakukan dengan pengenalan kondisi kawasan ini sehingga tindakan yang akan dilakukan lebih tepat. Tujuan penelitian ini adalah untuk mengenali kondisi ekosistem mangrove dan lingkungannya antara lain ancaman, kerentanan dan kerusakan yang bisa terjadi. Metode penelitian ini menggunakan analisis kualitatif semi-kuantitatif dengan statistik sederhana.. Pengambilan data dilakukan dengan analisis data sekunder dan observasi lapangan. Data yang diperoleh dianalisis menggunakan indeks ancaman gelombang terhadap ekosistem mangrove meliputi tinggi gelombang, arus, bentuk garis pantai dan ada tidaknya karang penghalang. Indikator tersebut merupakan indikator yang memperkuat besarnya energi gelombang. Kemudian mengguanakan indeks kerentanan mangrove dari gelombang meliputi luasnya vegetasi mangrove, zonasi mangrove dan fungsi hutan mangrove. Indikator tersebut akan memperkuat kondisi kerentanan mangrove dari gelombang. Selanjutnya tingkat kerusakaan menggunakan persamaan bencana, dimana tingkat ancaman dan kerentanan saling menguatkan terhadap kerusakan. Hasil analisis setiap indikator diklasifikasikan ke dalam 3 kelas menurut Rumus Sturgess, sedangkan tingkat kerusakan terhadap gelombang dikelaskan menurut matrik Peraturan KA BNPB No 02 Tahun 2012 yang dimodifikasi. Hasil penelitian antara lain (1) Ancaman gelombang terhadap ekosistem mangrove di Kawasan Konservasi Pulau Dua pada tingkat sedang (2) Kerentanan ekosistem mangrove terhadap gelombang di Kawasan Konservasi Pulau Dua pada tingkat sedang (3) Berdasarkan kondisi ancaman dan kerentanan maka dapat dilihat tingkat kerusakan pada kelas sedang. Dengan pengenalan kondisi ini diharapkan dapat menjadi pedoman bagi pemerintah maupun masyarakat untuk bertindak sebagai upaya pengantisipasian dan pengurangan kerusakan ekosistem mangrove dikarenakan gelombang.
\end{abstract}

Keywords: ancaman, kerentanan, mangrove

\section{LATAR BELAKANG}

Mangrove merupakan salah satu jenis dari keluarga ekosistem yang terdapat di Indonesia. Ekosistem mangrove pada umumnya terdapat di wilayah pesisir. Indonesia merupakan negara kepulauan (Archipelagic Country) yang terdiri dari 17.508 pulau dengan luas laut sekitar 5,8 juta $\mathrm{km} 2$ dan bentangan pantai sepanjang $81.000 \mathrm{~km}$. Dengan panjangnya garis pantai tersebut sudah sewajarnya Indonesia memiliki hutan mangrove terluas di dunia.

Luas ekosistem mangrove di Indonesia mencapai 75 persen dari total mangrove di Asia Tenggara, atau sekitar 27 persen dari luas mangrove di dunia. Saat ini, tercatat Indonesia mempunyai hutan mangrove seluas 9,36 juta hektar yang tersebar di seluruh Indonesia. Sekitar 48 persen atau seluas 4,51 juta hektar rusak sedang dan 23 persen atau 2,15 juta hektar lainnya rusak berat. Kerusakan hutan mangrove di Indonesia salah satunya disebabkan karena gelombang yang menimbulkan abrasi. Hal ini terjadi karena adanya pertemuan tiga kekuatan yaitu yang berasal daratan, perairan laut dan udara sehingga ekosistem ini dikenal sebagai ekosistem dinamik dan unik. Luas wilayah daratan Indonesia yang semakin menyempit merupakan salah satu dampak dari adanya gelombang laut yang mengabrasi pantai termasuk ekosstem mangrove sebagai pelindung.

Gelombang tersebut berupa gelombang yang terbentuk karena tiupan angin dan gelombang pasang surut yang terbentuk karena adanya gaya tarik menarik antara matahari, bulan dan bumi. Besarnya energi gelombang dipengaruhi oleh kondisi di sekitarnya dan akan mempengaruhi kedudukan garis pantai. Menurut Pratikto et al. (1997), Gelombang yang datang mendekati pantai cenderung mengepung tanjung, dan mengkonsentrasikan energinya disisi muka dan samping tanjung tersebut. Perlindungan ekstra sangat diperlukan untuk daerah pantai yang memiliki bagian yang menjorok kelaut. Sementara di daerah teluk, dimana garis pantai lebih panjang dibanding tanjung, energi gelombang cenderung disebar ke sepanjang garis pantai. Kawasan Konservasi Pulau Dua merupakan teluk dan tanjung, kawasan teluk masih aman dari terpaan gelombang namun kawasan tanjung memungkinkan mendapatkan terpaan energi gelombang yang besar yang mengancam keberadaan ekosistem mangrove. Berdasarkan pengamatan dapat dilihat kerusakan mangrove dan perubahan luas mmangrove di sepanjang pantai, beberapa pohon tumbang dan mati. Berdasarkan hasil penelitian 
Salam Tarigan (2007), adanya perubahan garis pantai di Pantai Utara Banten dan salah satunya dikarenakan abrasi dan sudah sampai ke tambak masyarakat. Hal ini menunjukkan adanya ancaman gelombang terhadap pantai di sepanjang pantai di daerah ini.

Mangrove memiliki banyak fungsi antara lain sebagai peredam gelombang dan abrasi, sebagai peredam intrusi, sebagai habitat berbagai macam spesies dan vegetasinya dapat dimanfaatkan untuk manusia. Begitu besarnya fungsi mangrove akan sangat mempengaruhi ketika terjadi kerusakan apalagi untuk Indonesia. Memelihara akan lebih mudah daripada memperbaiki kerusakan. Namun pada umumnya masyarakat bertindak menunggu setelah kerusakan terjadi. Dampak yang ditimbulkan akan lebih besar dan menjangkau berbagai aspek. Kerusakan dapat diminimalkan ketika mampu mengenali kondisi lingkungan yang mengancam dan kerentana ekosistem mangrove yang saling berinteraksi sehingga dapat memberikan pemeliharaan yang tepat sebelum terjadinya kerusakan. Berdasarkan masalah di atas dapat dilakukan penelitian untuk mencari tingkat ancaman, kerentanan ekosistem mangrove dan besarnya bencana di ekosistem mangrove.

\section{METODE}

Meode penelitian ini menggunakan analisis kualitatif semikuantitatif dengan statistik sederhana. Data diambil dari data sekunder dan observasi lapangan. Pengolahan data menggunakan indeks meliputi indeks menentukan bahaya dan kerentanan sebagai berikut.

\section{Indeks Ancaman}

\begin{tabular}{|c|c|c|c|c|}
\hline \multirow{2}{*}{$\begin{array}{l}\text { Komponen/ } \\
\text { Indikator }\end{array}$} & \multicolumn{3}{|c|}{ Kelas Indeks } & \multirow{2}{*}{$\begin{array}{c}\text { Bobot/ } \\
\text { Total }\end{array}$} \\
\hline & Rendah & Sedang & Tinggi & \\
\hline Tinggi & $<1 \mathrm{~m}$ & $1-2.5 \mathrm{~m}$ & $>2.5 \mathrm{~m}$ & $40 \%$ \\
\hline \multicolumn{5}{|l|}{ Gelombang } \\
\hline Arus & $<0.2$ & $0.2-0.4$ & $>0.4$ & $30 \%$ \\
\hline $\begin{array}{l}\text { Bentuk garis } \\
\text { pantai }\end{array}$ & Berteluk & Lurus & Bertanjung & $15 \%$ \\
\hline $\begin{array}{l}\text { Ada tidaknya } \\
\text { karang } \\
\text { penghalang }\end{array}$ & $\begin{array}{l}\text { Ada } \\
\text { melindungi }\end{array}$ & $\begin{array}{l}\text { Ada tidak } \\
\text { melindungi }\end{array}$ & Tidak ada & $15 \%$ \\
\hline \multicolumn{5}{|c|}{$\begin{array}{l}\text { Ancaman Gelombang }=(0,4 \mathrm{x} \text { skor tinggi gelombang })+(0,3 \\
\mathrm{x} \text { skor arus })+(0,15 \mathrm{x} \text { skor bentuk garis pantai })+(0,15 \mathrm{x} \\
\text { skor karang penghalang })\end{array}$} \\
\hline \multicolumn{5}{|c|}{$\begin{array}{l}\text { Sumber : Peraturan KA BNPB No } 02 \text { Tahun } 2012 \text { yang } \\
\text { dimodifikasi }\end{array}$} \\
\hline
\end{tabular}

\section{Klasifikasi Tingkat Ancaman}

Klasifikasi tingkat ancaman menggunakan rumus sturgess sebagai berikut.

Batas atas : 30

Batas bawah : 10

Kelas interval $=30-10 / 3=6$

\begin{tabular}{|c|c|c|}
\hline No & Skor & Kelas \\
\hline 1 & $10-16$ & Rendah \\
2 & $16-24$ & Sedang \\
3 & $>24$ & Tinggi \\
\hline
\end{tabular}

Indeks Kerentanan Lingkungan

\begin{tabular}{|c|c|c|c|c|}
\hline \multirow[b]{2}{*}{ Parameter } & \multirow{2}{*}{$\begin{array}{c}\text { Bobot } \\
(\%)\end{array}$} & \multicolumn{3}{|c|}{ Kelas } \\
\hline & & Rendah & Sedang & Tinggi \\
\hline $\begin{array}{l}\text { Hutan Bakau/ } \\
\text { Mangrove }\end{array}$ & $50 \%$ & $>80 \%$ & $40-80 \%$ & $<40 \%$ \\
\hline $\begin{array}{l}\text { Zonasi } \\
\text { mangrove }\end{array}$ & $30 \%$ & $\begin{array}{c}\text { Sesuai } \\
\text { zonasi } \\
\text { dan } \\
\text { teratur }\end{array}$ & $\begin{array}{c}\text { Sesuai } \\
\text { zonasi } \\
\text { namun } \\
\text { tidak } \\
\text { teratur }\end{array}$ & $\begin{array}{l}\text { Tidak } \\
\text { sesuai } \\
\text { zonasi }\end{array}$ \\
\hline $\begin{array}{l}\text { Fungsi hutan } \\
\text { mangrove }\end{array}$ & $20 \%$ & $\begin{array}{l}\text { Hutan } \\
\text { Lindung }\end{array}$ & $\begin{array}{l}\text { Hutan } \\
\text { Alam }\end{array}$ & $\begin{array}{c}\text { Hutan } \\
\text { Produksi/ } \\
\text { Ekonomi }\end{array}$ \\
\hline
\end{tabular}

Kerentanan Lingkungan $=(0,5 \mathrm{x}$ skor hutan bakau $)+(0,3 \mathrm{x}$ skor zonasi mangrove $)+(0,2 \mathrm{x}$ skor fungsi hutan mangrove $)$ Sumber : Peraturan KA BNPB No 02 Tahun 2012 yang dimodifikasi

Kerentanan $=(0,4 \mathrm{x}$ skor kerentanan sosial $)+(0,25 \mathrm{x}$ skor kerentanan ekonomi $)+(0,25 \mathrm{x}$ skor kerentanan fisik $)+(0,1$ $\mathrm{x}$ skor kerentanan lingkungan)

\section{Klasifikasi Tingkat Kerentanan}

Klasifikasi tingkat kerentanan menggunakan rumus sturgess sebagai berikut.

Batas atas : 30

Batas bawah : 10

Kelas interval $=30-10 / 3=6$

\begin{tabular}{ccc}
\hline No & Skor & Kelas \\
\hline 1 & $10-16$ & Rendah \\
2 & $16-24$ & Sedang \\
3 & $>24$ & Tinggi \\
\hline
\end{tabular}

Ekosistem Mangrove Pulau Dua merupakan kawasan konservasi sehingga unsur sosial, ekonomi dan fisik dapat diabaikan (nilai nol/0) karena unsur tersebut tidak terdapat di dalam kawasan konservasi ini.

\section{Tingkat Kerusakan Mangrove berdasarkan Gelombang}

Tingkat kerusakan menggunakan persamaan bencana/ kerugian yaitu sebagai berikut :

$$
\text { Bencana }=\text { Ancaman } \mathrm{x} \text { Kerentanan }
$$

Pengkelasan kerusakan mangrove berdasarkan gelombang didasarkan pada tabel silang ancaman dengan kerentanan seperti tabel berikut.

Tabel Silang Ancaman dengan Kerentanan

\begin{tabular}{|c|c|c|c|c|}
\hline \multirow{2}{*}{\multicolumn{2}{|c|}{ Potensi Kerugian }} & \multicolumn{3}{|c|}{ Kerentanan } \\
\hline & & Rendah & Sedang & Tinggi \\
\hline \multirow{3}{*}{ Aancaman } & Rendah & & & \\
\hline & Sedang & & & \\
\hline & Tinggi & & & \\
\hline \\
\hline \multicolumn{5}{|c|}{$\begin{array}{l}\text { Sumber : Perka BNPB No } 2 \text { Tahun } 2002 \text { yang dimodifikasi } \\
\qquad=\text { Tingkat Potensi Kerugian Tinggi }\end{array}$} \\
\hline & \multicolumn{4}{|c|}{$=$ Tingkat Potensi Kerugian Sedang } \\
\hline & \multicolumn{4}{|c|}{$=$ Tingkat Potensi Kerugian Rendah } \\
\hline
\end{tabular}




\section{HASIL DAN PEMBAHASAN}

\section{Tingkat Ancaman Gelombang Terhadap Ekosistem Mangrove}

Ancaman adalah suatu kejadian atau peristiwa yang bisa menimbulkan bencana (UU No 24 Tahun 2007). Tingkat ancaman gelombang dihitung berdasarkan indeks dengan memperhitungkan tinggi gelombang, arus, tutupan lahan/vegetasi, bentuk garis pantai. Hasil yang di dapat tinggi gelombang sebesar $0,7-1,8 \mathrm{~m}$; arus sebesar 0,15 ; bentuk garis pantai berupa tanjung dan tidak ada karang penghalang pada pantai ini. Berdasarkan hasil di atas dapat dihitung tingkat ancaman gelombang terhadap ekosistem mangrove pada tabel sebagai berikut.

Tabel ancaman gelombang

\begin{tabular}{|c|c|c|c|c|}
\hline \multirow{2}{*}{$\begin{array}{c}\text { Komponen/Ind } \\
\text { ikator }\end{array}$} & \multicolumn{3}{|c|}{ Kelas Indeks } & \multirow{2}{*}{$\begin{array}{c}\text { Bobot/T } \\
\text { otal }\end{array}$} \\
\hline & $\begin{array}{c}\text { Renda } \\
\mathbf{h}\end{array}$ & Sedang & Tinggi & \\
\hline $\begin{array}{l}\text { Tinggi } \\
\text { Gelombang }\end{array}$ & $<1 \mathrm{~m}$ & $1-2.5 \mathrm{~m}$ & $>2.5 \mathrm{~m}$ & $40 \%$ \\
\hline Arus & $<0.2$ & $0.2-0.4$ & $>0.4$ & $30 \%$ \\
\hline $\begin{array}{l}\text { Bentuk garis } \\
\text { pantai }\end{array}$ & $\begin{array}{c}\text { Bertelu } \\
\mathrm{k}\end{array}$ & Lurus & $\begin{array}{l}\text { Bertanj } \\
\text { ung }\end{array}$ & $15 \%$ \\
\hline $\begin{array}{l}\text { Ada tidaknya } \\
\text { karang } \\
\text { penghalang }\end{array}$ & $\begin{array}{l}\text { Ada } \\
\text { melindu } \\
\text { ngi }\end{array}$ & $\begin{array}{l}\text { Ada } \\
\text { tidak } \\
\text { melindu } \\
\text { ngi }\end{array}$ & $\begin{array}{l}\text { Tidak } \\
\text { ada }\end{array}$ & $15 \%$ \\
\hline \multicolumn{5}{|c|}{$\begin{array}{c}\text { Ancaman Gelombang }=(0,4 \times 20)+(0,3 \times 10)+(0,15 \times 30) \\
+(0,15 \times 20) \\
=8+3+4.5+3 \\
=20\end{array}$} \\
\hline
\end{tabular}

Pada tabel dapat dilihat tinggi gelombang berada di kelas sedang, sedangnya gelombang di Pulau Dua ini karena lokasinya tidak berbatasan dengan laut lepas sehingga angin permukaan tidak sebesar lokasi di Jawa bagian Selatan yang langsung berbatasan dengan samudra, selain itu dipengaruhi oleh laut yang cenderung tidak curam. Bentuk pantai yang berbentuk tanjung menyebabkan tingginya konsentrasi energi gelombang ke tempat ini sehingga berada di kelas yang tinggi.

Berdasarkan hasil perhitungan, ancaman Ekosistem Mangrove Pulau Dua terhadap gelombang mendapatkan nilai 2 dan berdasarkan klasifikasi sturgess berada di kelas sedang.Tingkat ancaman sedang ini dapat diartikan bahwa gelombang di Pantai Utara Banten khususnya di Kawasan Konservasi Mangrove Pulau Dua memungkinkan menyebabkan abrasi dan menimbulkan kerusakan yang wajar pada ekosistem mangrove di tempat tersebut jika kondisi ancaman seperti ketika dilakukan penelitian. Ancaman akan semakin besar ketika kondisi berubah pada variabel yang meningkatkan ancaman gelombang. Dapat dilihat pada tabel bahwa indikator yang paling mempengaruhi adalah tingginya gelombang sehingga ketika gelombang semakin tinggi maka dapat meningkatkan ancaman gelombang terhadap keberaadaan ekosistem mangrove ini.

\section{Tingkat Kerentanan Ekosistem Mangrove terhadap Gelombang}

Kerentanan adalah suatu kondisi dari suatu komunitas atau masyarakat yang mengarah atau menyebabkan ketidakmampuan dalam menghadapi ancaman bencana (UU No 24 Tahun 2007.). Tingkat kerentanan ekosistem mangrove di Pulau Dua terhadap gelombang dihitung berdasarkan kerentanan ekonomi, sosial, fisik dan lingkungan. Pulau Dua yang merupakan wilayah konservasi tidak memungkinkan adanya aktivitas masyarakat secara umum sehingga kegiatan sosial, ekonomi dan keberadaan infrastruktur secara fisik dinyatakan mendapatkan nilai nol/0 sehingga yang dihitung adalah kerentanan lingkungan mangrove yang meliputi perhitungan keberadaan hutan mangrove, zonasi hutan mangrove dan fungsi hutan mangrove sebagai hutan lindung.

Tabel kerentanan mangrove

\begin{tabular}{|c|c|c|c|c|}
\hline \multirow{2}{*}{ Parameter } & \multirow{2}{*}{$\begin{array}{c}\text { Bobot } \\
(\%)\end{array}$} & \multicolumn{3}{|c|}{ Kelas } \\
\hline & & Rendah & Sedang & Tinggi \\
\hline $\begin{array}{c}\text { Hutan Bakau/ } \\
\text { Mangrove }\end{array}$ & $50 \%$ & $>80 \%$ & $40-80 \%$ & $<40 \%$ \\
\hline $\begin{array}{c}\text { Zonasi } \\
\text { mangrove }\end{array}$ & $30 \%$ & $\begin{array}{l}\text { Sesuai } \\
\text { zonasi } \\
\text { dan } \\
\text { teratur }\end{array}$ & $\begin{array}{c}\text { Sesuai } \\
\text { zonasi } \\
\text { namun } \\
\text { tidak } \\
\text { teratur }\end{array}$ & $\begin{array}{l}\text { Tidak sesuai } \\
\text { zonasi }\end{array}$ \\
\hline $\begin{array}{c}\text { Fungsi hutan } \\
\text { mangrove }\end{array}$ & $20 \%$ & $\begin{array}{l}\text { Hutan } \\
\text { Lindung }\end{array}$ & $\begin{array}{l}\text { Hutan } \\
\text { Alam }\end{array}$ & $\begin{array}{c}\text { Hutan } \\
\text { Produksi/Ekonomi }\end{array}$ \\
\hline Kerentan & Lingk & $\begin{array}{r}\operatorname{san}=(0,5 \\
=10+ \\
=1\end{array}$ & $\begin{array}{l}20)+(0, ? \\
-1\end{array}$ & $20)+(0,1 \times 10)$ \\
\hline
\end{tabular}

Pada tabel dapat dilihat vegetasi mangrove sebesar 40$80 \%$ karena ada beberapa lokasi yang mengalami kerusakan sehinga mengurangi kekuatan mangrove. Zonasi di Pulau Dua dari laut ke darat yaitu pada tanjung Pulau Dua yaitu formasi Diospyros maritima, formasi Pempis sp dan Thespesia sp, dan pada pantai yaitu formasi Avicenia sp, formasi Rhizophora sp. Pengakaran yang paling kuat dimiliki oleh formasi Avicenia sp yang seharusnya juga diletakkan pada tanjung Pulau Dua. Pulau Dua merupakan hutan lindung/konservasi sehingga tingkat penggunaan secara umum dapat diminimalkan serta pengawasannya lebih ketat sehingga dikelaskan pada klasifikasi rendah karena tingkat pengrusakannya dapat diminimalkan.

Berdasarkan hasil perhitungan, kerentanan Ekosistem Mangrove Pulau Dua terhadap gelombang mendapatkan nilai 2 dan berdasarkan klasifikasi sturgess berada di kelas sedang. Tingkat kerentanan sedang ini dapat diartikan bahwa Ekosistem Mangrove Pulau Dua dapat terkena abrasi dan mengalami kerusakan ekosistem dalam keadaan kondisi lingkungan seperti pada saat dilakukan penelitian. Indikator yang paling mempengaruhi adalah keberadaan vegetasi mangrove, kerentanan ekosistem akan semakin meningkat jika keberadaan mangrove semakin berkurang karena tidak ada pembaharuan atau terjadi kerusakan. 


\section{Tingkat Kerusakan Mangrove berdasarkan \\ Gelombang}

Tingkat kerusakan menggunakan persamaa bencana. Ancaman akan menjadi bencana ketika terdapat kerugian dalam suatu kejadian. Tingkat kerusakan dipengaruhi oleh ancaman dan kerentanan. Ancaman dan kerentanan bersifat saling menguatkan. Berdasarkan tabel silang dengan menyilangkan tingkat ancaman sedang dan tingkat kerentanan sedang maka tingkat bencana/kerugian sedang. Tingkat kerusakan sedang ini memungkinkan menimbulkan kerugian. Kawasan ini merupakan kawasan konservasi sehingga kerugian dialami oleh pemerintah daerah namun tidak menutup kemungkinan ketika ancaman dan kerentanan semakin besar maka bencana dan kerugian juga semakin besar, tidak hanya wilayah konservasi yang rusak namun bisa sampai ke lahan masyarakat sehingga masyarakat juga akan menderita kerugian. Dengan demikian sebisa mungkin bencana dan kerugian dapat dihindarkan dengan cara meningkatkan kapasaitas/kemampuan kawasan sebagai faktor pengurang besarnya ancaman dan kerentanan.

\section{KESIMPULAN}

Berdasarkan hasil penelitian di atas dapat diambil kesimpulan sebagai berikut :

1. Ancaman gelombang terhadap ekosistem mangrove di Kawasan Konservasi Pulau Dua pada tingkat sedang yang dipengaruhi oleh gelombang sedang dan bentuk pantai yang bertanjung.

2. Kerentanan ekosistem mangrove terhadap gelombang di Kawasan Konservasi Pulau Dua pada tingkat sedang yang dipengaruhi oleh beberapa vegetasi di bibir pantai yang rusak dan kerusakan mangrove di tempat lainnya yang mengurani kekuatan vegetasi mangrove yang menjadikan perubahan zonasi yang juga mengurangi kekuatan kawasan mangrove.

3. Berdasarkan kondisi ancaman dan kerentanan maka dapat dilihat tingakt kerusakan pada kelas sedang. Dengan pengenalan kondisi ini diharapkan dapat menjadi pedoman bagi pemerintah maupun masyarakat untuk bertindak sebgai upaya pengantisipasian dan pengurangan kerusakan ekosistem mangrove dikarenakan gelombang.

\section{DAFTAR PUSTAKA}

Peraturan Kepala Badan Nasional Penanggulangan Bencana Nomor 02 Tahun 2013 Tentang Pedoman Umum Pengkajian Risiko Bencana

Pratikto, W.A, Armono H.D, Suntoyo. (1997). Perencanaan Fasilitas Pantai Dan Laut. Edisi Pertama. Bpfe. Yoyakarta. $226 \mathrm{Hlm}$.

Tarigan, Salam, M. (2005). Perubahan Garis Pantai Di Wilayah Pesisir Perairan Cisadane, Provinsi Banten. Jurnal. Bidang Dinamika Laut, Pusat Penelitian Oseanografi, Lembaga Ilmu Pengetahuan Indonesia. Jakarta

Undang-Undang No. 24 Tahun 2007 Tentang Penanggulangan Bencana 